\title{
The first fossil Discolomatidae (Coleoptera) from Hispaniola
}

\author{
Karol Szawaryn ${ }^{1}\left[\right.$. Janusz Kupryjanowicz ${ }^{2}$
}

Received: 22 November 2018 / Accepted: 27 May 2019 / Published online: 18 June 2019

(c) The Author(s) 2019

\begin{abstract}
Discolomatidae are a small beetle family distributed in subtropical to tropical ecosystems. Many of the modern members of the genus Fallia Sharp inhabit Central America while some species occur on Hispaniola, the Galapagos Islands, and the Hawaiian islands. A new fossil species belonging to the same genus, F. palaeodominicana sp. nov., has been found in a piece of Dominican amber, and described as the first fossil member of the family. The presence of extant as well as extinct species of Fallia on Hispaniola provokes questions about the age and origin of the genus Fallia and how long ago it settled Hispaniola.
\end{abstract}

Keywords Coccinelloidea $\cdot$ Fallia $\cdot$ New species $\cdot$ Dominican amber $\cdot$ Paleoentomology

\section{Introduction}

The family Discolomatidae Horn, 1878 has a complex taxonomic history (Cline and Ślipiński 2010), however recent molecular data has confirmed its placement in the superfamily Coccinelloidea (Robertson et al. 2015) within the bothriderid group of families (Bothrideridae Erichson, Ceryloniade Billberg, Discolomatidae Horn, Euxestidae Grouvelle, Murmidiidae Jacquelin Du Val, Teredidae Seidlitz) as a sister group to the newly erected family Murmidiidae. Monophyly of discolomatids is well supported by several unique apomorphies including adults with glandular openings lining the lateral pronotal and elytral margins and the mesoand metacoxaelong and transverse but nearly concealed by meso- and metaventral plates. The age of the family is estimated based on molecular phylogenetic reconstructions from around $110 \mathrm{Ma}$ (Zhang et al. 2018) to $142 \mathrm{Ma}$ (McKenna et al. 2015), but no fossil records had been found until now.

Handling Editor: Mike Reich.

Karol Szawaryn

k.szawaryn@gmail.com

Janusz Kupryjanowicz

kuprzool@uwb.edu.pl

1 Museum and Institute of Zoology, Polish Academy of Sciences, Wilcza 64, 00-679 Warsaw, Poland

2 Andrzej Myrcha Nature Center, University of Białystok, ul. Ciołkowskiego 1J, 15-245 Białystok, Poland
The biology of discolomatids is poorly studied, but in general they are regarded as fungivores (Cline and Ślipiński 2010), and have been found in leaflitter, subcortical spaces, compost heaps, and polypore fungi. Some species are thought to be myrmecophilous, and were collected in ant nests (Cline and Ślipiński 2010).

Discolomatidae is a relatively small beetle family containing about 400 extant species grouped in 16 genera (John 1959a; Cline and Ślipiński 2010). A majority of species are distributed in the Afrotropical and Oriental regions. The New World fauna consists of about 45 extant species belonging to 4 genera: Discoloma Erichson, 1845, Fallia Sharp, 1902, Holophygus Sharp, 1899 and Solitarius John, 1943 (Cline and Ślipiński 2010).

The genus Fallia Sharp contains 9 extant species (Fig. 1) (Sharp 1902; Scott 1908; John 1944, 1959b; see checklist in Cline and Shockley 2012). Most of the extant Fallia species inhabit Central America and Caribbean regions (5 species), two species are known from the Galapagos Islands and one from Bahia in Brazil (Fig. 1). The ninth species was described from the Hawaiian Islands, but its status as native or adventive has not been resolved (Cline and Shockley 2012). The genus is characterized by: antennae consisting of 8 or 9 antennomeres; meso-metaventral junction straight; pronotum truncate at anterior margin (not so rounded as in Aphanocephalus Wollaston, 1873); elytra with elytral margin narrow but entirely visible from above; and mesosternum longer than its width.

The age of Dominican amber deposits has been discussed by several authors and, based on the place of origin, it was 
Fig. 1 Distribution of extant and extinct species of the genus Fallia Sharp

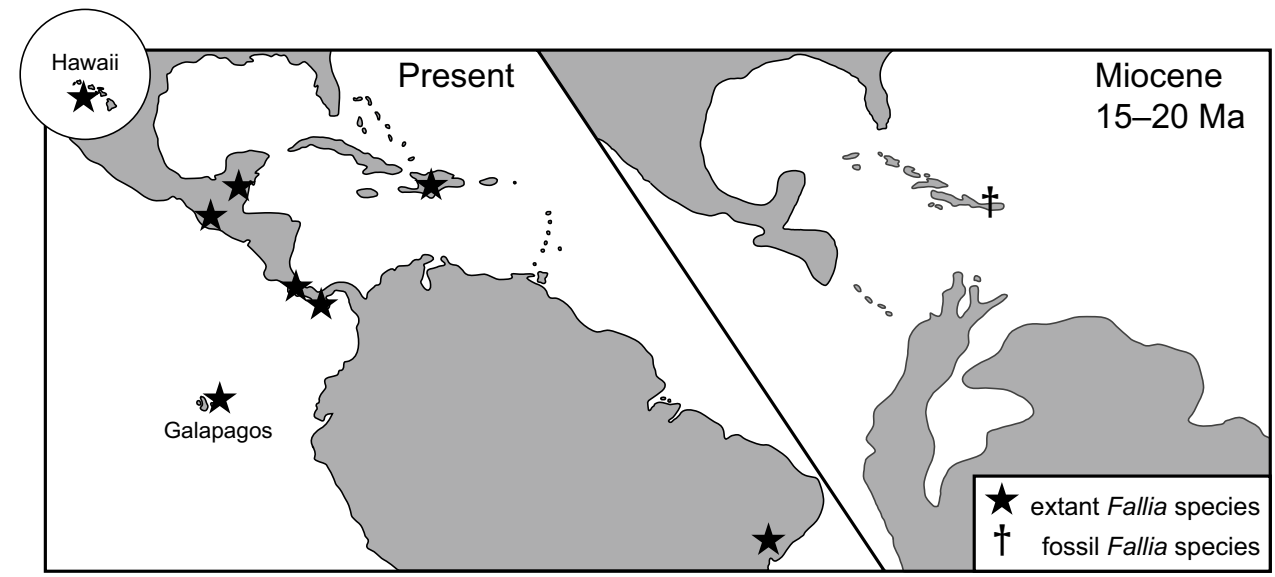

concluded that it dated back to the early Middle Miocene (15-20 Ma) (Grimaldi 1994; Iturralde-Vinent and MacPhee 1996; Iturralde-Vinent 2001; Grimaldi and Engel 2005; Penney 2010). That period corresponds to the Middle Miocene Climate Optimum (MMCO) when a global warming period was occurring (You et al. 2009), and tropical zones had expanded their ranges (Pound et al. 2012). Fossils discovered from Dominican amber enable a possible reconstruction of the environment of the 'Dominican amber forest' as similar to that of present-day tropical moist forest (Poinar and Poinar 1999).

\section{Materials and methods}

This study is based on a Dominican amber piece that came from the private collection of Janusz Kupryjanowicz (Białystok, Poland), and will be deposited in the Andrzej Myrcha Nature Center at the University of Białystok (UCPUwB) with the collection number UCPUwB 1024. The material was polished manually with emery papers of different grain sizes and subsequently lustrated with polishing powder. The specimen was examined and photographed with a Leica M205A stereomicroscope with Leica DM 6000 digital camera attached to a Leica Application Suite LAS 3.7. Total length (TL) is defined as the distance from the anterior margin of the pronotum to the apex of the elytra, and total width was measured at the widest point across the elytra. Pronotal length (PL) was the length measured at the midline from the anterior to posterior margin, and pronotal width (PW) was measured at the widest point across the pronotum. Elytral length (EL) was measured from the anterior margin to the apex along the suture, and elytral width (EW) was measured at the widest point across both elytra. Mesosternal length (MsL) was the length measured at the midline from the anterior to posterior margin, and mesosternal width $(\mathrm{MsW})$ was measured at the widest point across the metaventrite; metasternal length $(\mathrm{MtL})$ and $(\mathrm{MtW})$ were measured as for mesosternum. Terminology used in this paper follows Cline and Ślipiński (2010), Lawrence et al. (2011) and Cline and Shockley (2012).

To confirm the origin of the amber sample designated as the holotype, Fourier transform infrared (FT-IR) spectra were obtained (Szwedo and Stroiński 2017; Szawaryn and Szwedo 2018) in the Laboratory of the International Amber Association, Gdańsk, Poland, with a Nicoleti S10 spectrometer with an attenuated total reflectance (ATR) accessory. A reference curve number in the collection archives serves as the registration number of the specimen, with suffix 'IR'.

\section{Systematic palaeontology}

Order Coleoptera Linnaeus, 1758

Suborder Polyphaga Emery, 1886

Superfamily Coccinelloidea Latreille, 1807

Family Discolomatidae Horn, 1878

Subfamily Aphanocephalinae Grouvelle, 1912

Genus Fallia Sharp, 1902

Type species. Fallia synthetica Sharp, 1902, subsequent designation.

Fallia palaeodominicana sp. nov.

Figure 2a-g

Etymology. Specific epithet derived from the type localityDominican Republic, and prefix ‘palaeo' meaning ancient.

Holotype. No 1024 (coll. J. Kupryjanowicz). Reference IR curves no. UCPUwB IR (Fig. 3) and deposited in UCPUwB. Piece of Dominican amber from La Toca Mines, transparent yellow, anterior right part of the inclusion covered with a milky veil. Cuticle brown without any trace of maculation. No syninclusions. 
Locality and Horizon. Amber mine in the Cordillera Septentrional of the northern portion of the Dominican Republic, La Toca. Suite of clastic rocks from the upper part of the $\mathrm{La}$ Toca Formation, Early to early Middle Miocene 15-20 Ma (Iturralde-Vinient and MacPhee 1996).

Diagnosis. F. palaeodominicana is slightly more elongate than $F$. iviei with the length to width ratios 1.4 and 1.3, respectively. It is also rather flattened, while $F$. iviei is more hemispherical. The difference can be also observed in punctation of pronotum and elytral disc which is fine in F. iviei and more coarse with punctures distributed more densely in F. palaeodominicana.

Description. Length $=1.78 \mathrm{~mm}$; width $=1.28 \mathrm{~mm}$; TL/ $\mathrm{EW}=1.39 ; \mathrm{PL} / \mathrm{PW}=0.57 ; \mathrm{PL} / \mathrm{EL}=0.43 ; \mathrm{PW} / \mathrm{EW}=0.76$; $\mathrm{EL} / \mathrm{EW}=1.00 ; \mathrm{MsL} / \mathrm{MsW}=0.94 ; \mathrm{MtL} / \mathrm{MtW}=0.32$. Body round, slightly elongate (Fig. 2a, b), flattened (Fig. 2g); widest across middle of elytra; pronotal and elytral margins visible from above.

Head-Entirely visible (Fig. 2g), slightly declined, not retracted underneath pronotum (outstretched); eyes large; temples about $1.5 \times$ longer than eye length. Shape somewhat rectangular, lateral margins of fronto-clypeal region not distally convergent. Antennal insertions fully exposed, medially positioned on vertex between eyes. Surface glabrous with minute, irregular punctures. Antennal grooves short, extending along ventral margin of eye. Vertex convex. Fronto-clypeal suture conspicuous and evenly arcuate between antennal insertions. Clypeus large and moderately convex, about twice as broad as its length. Eyes prominent, rounded, coarsely faceted, with no interfacetal setae (Fig. 2e). Antennae 9-segmented with annulate 1-segmented club (Fig. 2e). Scape elongated, more than $2 \times$ longer than pedicel; pedicel barrel-shaped, antennomere 3 elongated about $1.5 \times$ longer than antennomere 4 , antennomere 4 longer than pedicel; antennomere 5 about as long as pedicel; antennomeres 6-8 subequal slightly elongated, shorter than pedicel. Club elongate with broadly rounded apex and narrowed base; club as long as segments 5-8 combined. Terminal segment with apex bearing several elongate setae extending beyond the apical margin. Labrum transverse, about $2 \times$ broader than its length, anterior margin broadly concave. Mandibles apically bifid. Ventral mouthparts (including maxillary and labial palpi) clearly visible from below (Fig. 2g). Clypeo-labral suture concave. Maxillary palpi well-developed, 3-segmented, terminal segment conical with entire apex covered with sensory pegs. Labial palpi well-developed, 3-segmented, terminal segment conical with entire apex covered with sensory pegs.

Prothorax-Pronotum transverse, widest at posterior angles, flattened, coarsely punctate, with punctures more dense than those on elytra, separated by $1-2$ times their diameter. Anterior angles broadly rounded, posterior angles distinct. Lateral margins narrowly explanate, evenly and arcuately convergent toward anterior angles. Lateral marginal bead with 2 secretory pores, 1 near 0.2 and 1 near 0.8 length from posterior angles (Fig. 2b, g). Anterior margin broadly concave. Posterior margin broadly sinuate. Posterior margin bordered. Length between anterior margin of procoxal cavities and anterior margin of prosternum shorter than length of mesosternum (Fig. 2d). Prosternum with welldeveloped, oblique impressions anterior to coxal cavities extending antero-laterally from the procoxae, for reception of protibiae in repose (Fig. 2d). Prosternal process extending posterior procoxae; in lateral view, flat. Procoxal cavities separated by $1 \times$ procoxal cavity width.

Pterotorax-Scutellum visible, triangular (Fig. 2b); similar surface punctation as on pronotum. Mesosternum welldeveloped, flat, and at same level as metasternum; surface punctation faint. Meso-metasternal junction concave with anterior margin of metasternum broadly convex. Mesocoxal cavities separated by more than mesosternum length in midline. Metasternum transverse; metasternal disc punctation faint, punctures minute; lateral regions of metasternum with rugose microsculpturing present. Postcoxal lines of mesocoxae absent on metasternum. Metacoxal cavities separated by almost $3 \times$ procoxal cavity width. Elytra with lateral margins narrowly explanate. Each elytron bearing 6 secretory pores along the lateral margin (Fig. 2b, e). Punctation more fine and sparse than those on pronotum, with punctures separated by 3-4 times their diameter. Humeral angles not raised. Wings not visible.

Legs-Tibiae and femora strongly flattened (Fig. 2a, f). All femora excavated for reception of tibiae. All femora and tibiae elongate elliptical, widest near middle. Each tibia with small, stiff spines present along posterior margin. Tarsal formula 3-3-3 (Fig. 2f); tarsi simple with some projecting setae ventrally; claws simple with small basal angulation (Fig. 2c).

Abdomen-Abdomen with five ventrites (Fig. 2f). Abdominal ventrite 1 broadly truncate between metacoxae, large, about as long as ventrites $2-4$ combined. Ventrites 2-4 subequal in length, ventrite 5 slightly longer, broadly rounded at posterior margin. Sex undetermined. Genitalia not visible.

\section{Discussion}

The Dominican amber inclusion described above can be immediately classified as a member of the family Discolomatidae because of the presence of a lateral row of six secretory pores on each elytron and two on each side of the pronotum, which is unique to this family of beetles. The beetle also possesses globular coxae and trimerous tarsi. Although the current classification system of Discolomatidae is 


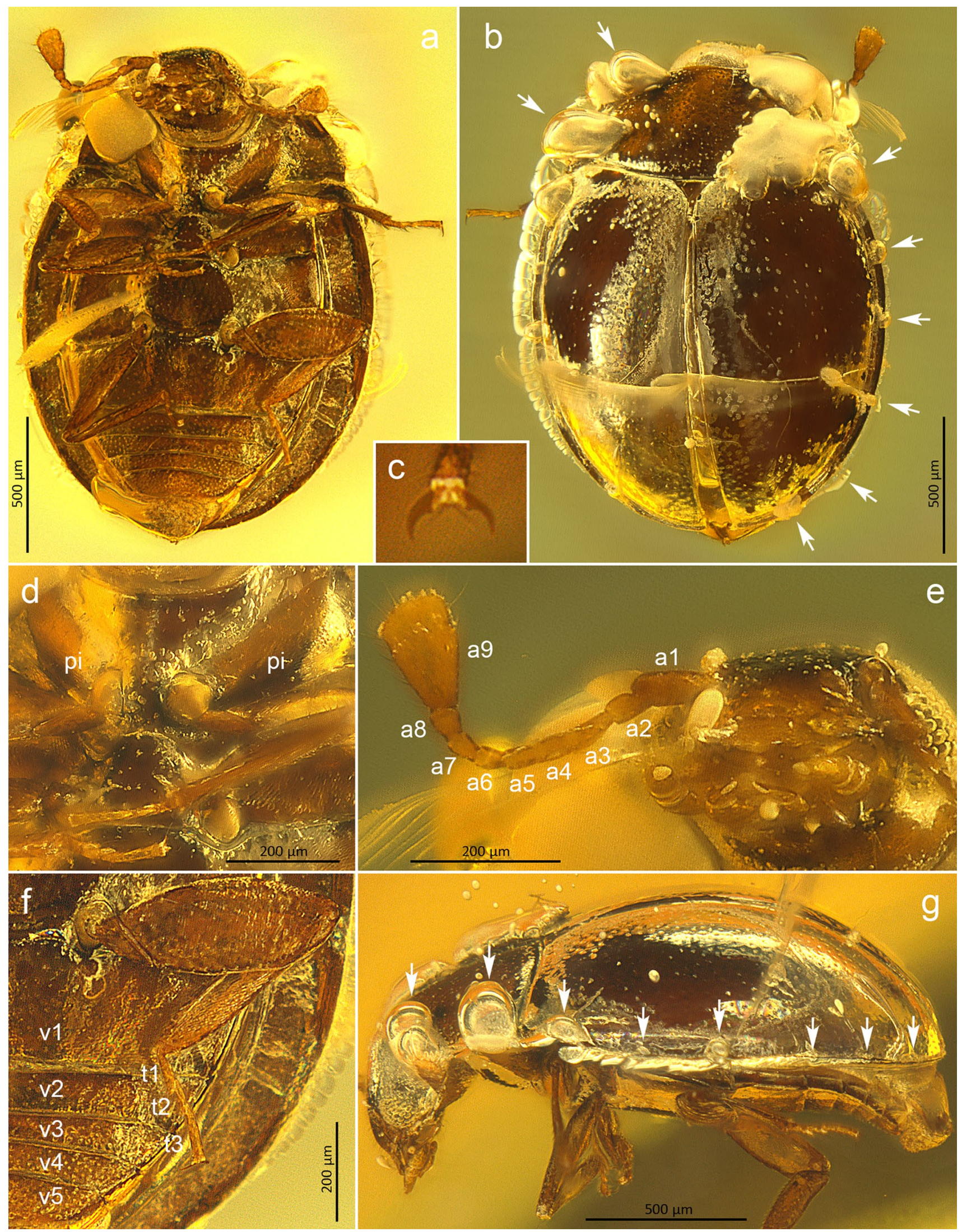


4Fig. 2 Fallia palaeodominicana sp. nov., holotype UCPUwB 1024. a Habitus, ventral, b habitus, dorsal, $\mathbf{c}$ tarsal claw, d pronotum and mesoventrite, e head, mouthparts and antenna, $\mathbf{f}$ hind leg and abdomen, $g$ habitus, lateral. Arrows indicate gland openings, a1 -7 numbers of antennomeres, $v 1-5$ numbers of ventrites, $\mathrm{t} 1-3$ numbers of tarsomeres. pi Prosternal impressions

typological, the following characters enable the authors to place the newly described species in the genus Fallia: head not covered by the pronotum, nine segmented antennae, elongated mesoventrite (not transverse as in Aphanocephalus), glabrous dorsal surface (setose in Holophygus Sharp, 1899, Parafallia Arrow, 1939), rounded elytral margin (not corrugated as in Holophygus, Notophygus Gory, 1834), elytral margin with narrow lateral margin (broadly extended in Discoloma Erichson, 1845, Cassidoloma Kolbe, 1897).

No phylogenetic analysis is available for Fallia nor for Discolomatidae, thus any discussion about the biogeography and evolution of that genus in Mesoamerica is highly theoretical. Nonetheless, the presence of the extant $F$. iviei Cline and Shockley, as well as fossil species of Fallia on Hispaniola, provoke questions about the age of the genus Fallia and how long ago it settled the island. Was Hispaniola independently settled twice by the Fallia species (in Miocene and more recent times), or is $F$. palaeodominicana an ancestor of modern F. iviei? This newly described species is the first fossil representative recorded for the family
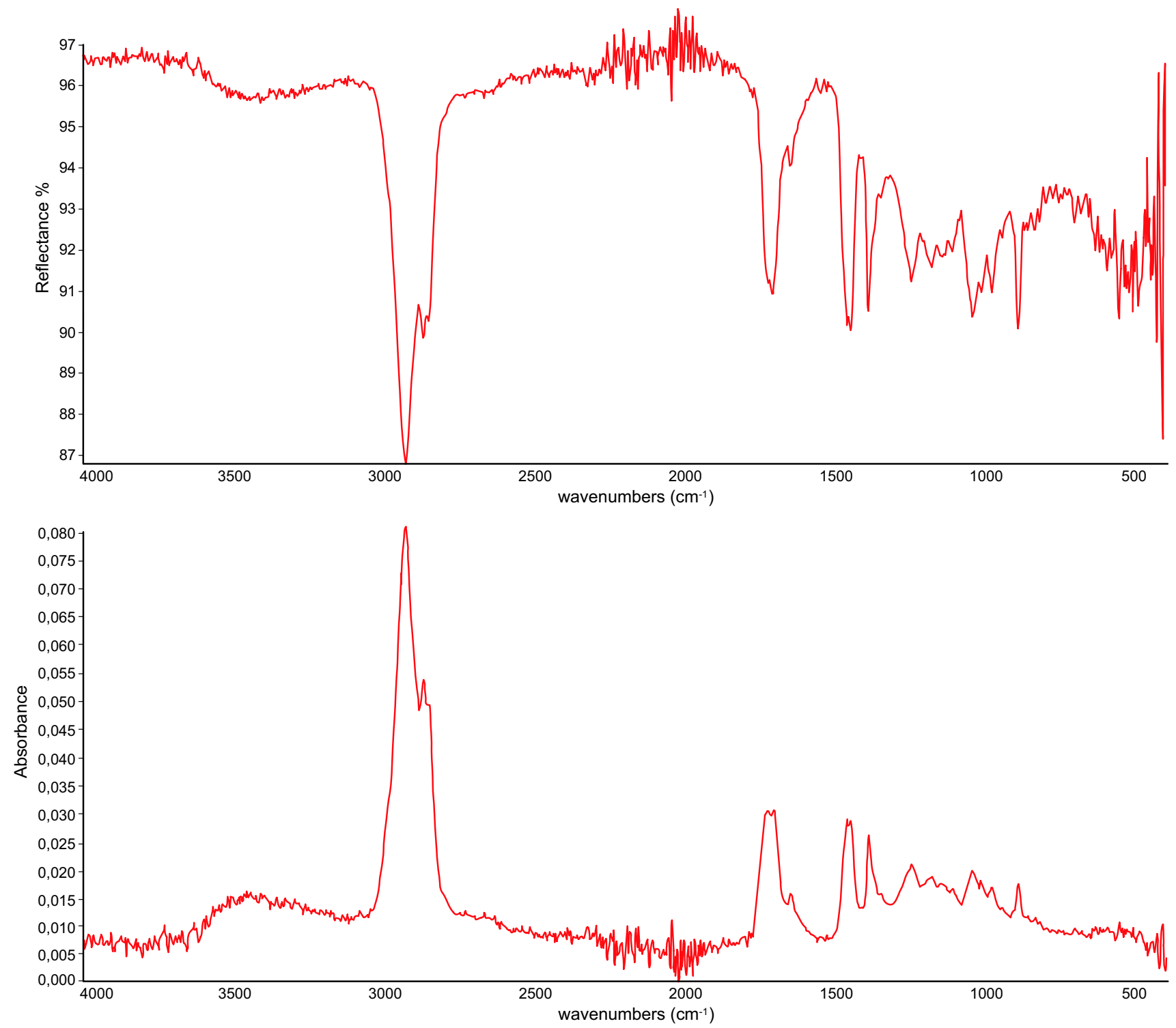

Fig. 3 FT-IR spectra of analysed amber piece UCPUwB 1024. Top—reflectance spectrum, bottom—absorbance spectrum 
Discolomatidae, and it can be potentially used for time-tree calibration in the future phylogenetic analyses.

Acknowledgements We would like to thank Agnieszka Klikowicz (International Amber Association, Gdańsk) for her kind help with obtaining FT-IR spectra, and Ewa Wysiecka-Wegner (Gdańsk University of Technology) is acknowledged for the analysis of spectrum and confirmation of authenticity of the amber piece. Jacek Szwedo is acknowledged for valuable comments on the early draft of this manuscript. Alexander Kirejtshuk and second anonymous reviewer are acknowledged for their constructive and helpful comments.

Open Access This article is distributed under the terms of the Creative Commons Attribution 4.0 International License (http://creativeco mmons.org/licenses/by/4.0/), which permits unrestricted use, distribution, and reproduction in any medium, provided you give appropriate credit to the original author(s) and the source, provide a link to the Creative Commons license, and indicate if changes were made.

\section{References}

Arrow, G.J. 1939. Entomological results for the Swedish expedition 1934 to Burma and British India. Coleoptera: Clavicornia. Erotylidae, Languriidae, Endomychidae. Discolomidae \& Georyssidae. Arkiv för Zoologi 31(17): 1-9.

Cline, A.R., and F.W. Shockley. 2012. A new species of Fallia Sharp (Cucujoidea: Discolomatidae) from the West Indies, with a world checklist for Fallia. The Coleopterist Bulletin 66(2): 93-99.

Cline, A.R., and A. Ślipiński. 2010. Discolomatidae Horn, 1878. In Handbook of Zoology. Volume IV. Arthropoda: Insecta. Part 38. Coleoptera, Beetles. Volume 2: Morphology and Systematics (Elateroidea, Bostrichiformia, Cucujiformia partim), eds. R.A.B. Leschen, R.G. Beutel, and J.F. Lawrence, 435-442. Berlin, Boston: W. DeGruyter.

Emery, C. 1886. Über Phylogenie und Systematik der Insekten. Biologisches Zentralblatt 5: 648-656.

Erichson, W.F. 1845. Naturgeschichte der Insecten Deutschlands. Erste Abtheilung. Coleoptera. Dritter Band. Berlin: Nicolaische Buchhandlung.

Gory, M. 1834. Monographie du genre Notophygus. Annales de la Societe entomologique de Francaise 3: 453-457.

Grimaldi, D.A. 1994. The age of Dominican amber. In Amber, resinite, and fossil resins, eds. K.B. Anderson and J.C. Crelling, 203-217. Washington D.C.: American Chemical Society.

Grimaldi, D.A., and M.S. Engel. 2005. Evolution of the insects. New York: Cambridge University Press.

Grouvelle, A. 1912. Étude sur les Aphanocephalus et descriptions d'espèces nouvelles. Notes from the Leyden Museum 34(3/4): 197-224.

Horn, G.H. 1878. Synopsis of the Colydiidae of the United States. Proceedings of the American Philosophical Society 17: 555-592.

Iturralde-Vinent, M.A. 2001. Geology of the amber-bearing deposits of the Greater Antilles. Caribbean Journal of Science 37: 141-167.

Iturralde-Vinent, M.A., and R.D.E. MacPhee. 1996. Age and paleogeographical origin of Dominican amber. Science 273: 1850-1852.

John, H. 1943. Solitarius, eine neue Gattung der Notiopygidae (=Discolomatidae) Col. Entomologische Blätter 39: 28-30.

John, H. 1944. Zwei neue Spezies der Gattung Fallia Sharp (Notiophygidae). Entomologische Blätter 40: 87-90.

John, H. 1959a. Coleoptera Clavicornia. Fam. Discolomatidae (=Notiophygidae). In Genera Insectorum, Fascicule 213, ed. P. Wytsman, 1-56. Brussels: SPRL Imprimerie \& Éditions Mercurius.
John, H. 1959b. Neue Spezies der Gattungen Notiophygus Gory und Fallia Sharp (Ins., Col., Discolomidae $=$ Notiophygidae). Senck enbergiana biologica 40: 289-296.

Kolbe, H. 1897. Coleopteren. Die Käfer Deutsch-Ost-Afrikas. Berlin: D. Reimer.

Latreille, P.A. 1807. Genera crustaceorum et insectorum secundum ordinem naturalem in familias disposita, iconibus exemplisque plurimis explicata. Tomus tertius. Paris: A. Koenig.

Lawrence, J.F., A. Ślipiński, A. Seago, M. Thayer, A. Newton, and A. Marvaldi. 2011. Phylogeny of the Coleoptera based on adult and larval morphology. Annales Zoologici 61: 1-217.

Linnaeus, C. 1758. Systema naturae per regna tria maturae, secundum classes, ordines, genera, species cum characteribus, differentiis, synonymis, locis, vol. 1, Edn 10 (reformata). Holmiae [= Stockholm]: Laurentii Salvii.

McKenna, D.D., A.L. Wild, K. Kanda, C.L. Belamy, R.G. Beutel, M.S Caterino, C.W. Farnum, D.C. Hawks, M.A. Ivie, M.L. Jameson, R.A.B. Leschen, A.E. Marvaldi, J.V. McHugh, A.F. Newton, J.A. Robertson, M.K. Thayer, M.F. Whitng, J.F. Lawrence, A. Ślipiński, D.R. Maddison, and B.D. Farrel. 2015. The beetle tree of life reveals that Coleoptera survived end-Permian mass extinction to diversify during the Cretaceous terrestrial revolution. Systematic Entomology 40: 835-880.

Penney, D. 2010. Dominican amber. In Biodiversity of fossils in amber from the major world deposits, ed. D. Penney, 22-41. Manchester: Siri Scientific Press.

Poinar, G.O., and R. Poinar. 1999. The Amber forest: A Reconstruction of a Vanished World. Princeton: Princeton University Press.

Pound, M.J., A.M. Haywood, U. Salzmann, and J.B. Riding. 2012. Global vegetation dynamics and latitudinal temperature gradients during the Mid to Late Miocene (15.97-5.33 Ma). Earth-Science Reviews 112(1): 1-22.

Robertson, J.A., A. Ślipiński, M. Moulton, F.W. Shockley, A. Giorgi, N.P. Lord, D.D. McKenna, W. Tomaszewska, J. Forrester, K.B. Miller, M.F. Whiting, and J.V. McHugh. 2015. Phylogeny and classification of Cucujoidea and the recognition of a new superfamily Coccinelloidea (Coleoptera: Cucujiformia). Systematic Entomology 40: 745-778.

Scott, H. 1908. Fam Discolomidae. In Fauna Hawaiiensis, Volume III, Part V, Coleoptera III, eds. D. Sharp and H. Scott, 431-434. Cambridge: Cambridge University Press.

Sharp, D. 1899. Coleoptera [diverse families]. In Biologia CentraliAmericana. Insecta. Coleoptera. Vol 2, part 1, eds. F.D. Godman and O. Salvin, 497-498. London: Taylor and Francis.

Sharp, D. 1902. Fam Lathridiidae [Merophysiinae: Fallia]. In Biologia Centrali-Americana Insecta Coleoptera Vol 2, part 1, eds. F.D. Godman and O. Salvin, 629-631. London: Taylor and Francis.

Szawaryn, K., and J. Szwedo. 2018. Have ladybird beetles and whiteflies co-existed for at least 40 Mya? PalZ. Paläontologische Zeitschrift 92(4): 593-603

Szwedo, J., and A. Stroiński. 2017. Who's that girl? The singular Tropiduchidaeplanthopper from the Eocene Baltic amber (Hemiptera: Fulgoromorpha). Palaeontologia Electronica 20(3): 1-20.

Wollaston, T.V. 1873. On a new Coleopterous genus from Japan. The Entomologist's Monthly Magazine 9: 278.

You, Y., M. Huber, R.D. Müller, C.J. Poulsen, and J. Ribbe. 2009. Simulation of the Middle Miocene Climate Optimum. Geophysical Research Letters 36: L04702. https://doi.org/10.1029/2008G L036571.

Zhang, S.-Q., L.-H. Che, Y. Li, D. Liang, H. Pang, A. Ślipiński, and P. Zhang. 2018. Evolutionary history of Coleoptera revealed by extensive sampling of genes and species. Nature Comunications 9: 205 